\title{
Medicinal Properties and In Vitro Biological Activities of Selected Helichrysum Species from South Africa: A Review
}

\author{
Kolajo Adedamola Akinyede 1,2,*, Christopher Nelson Cupido ${ }^{3}$, Gail Denise Hughes ${ }^{1}$, \\ Oluwafemi Omoniyi Oguntibeju 4 (1) and Okobi Eko Ekpo ${ }^{1,5, *}$
}

1 Department of Medical Bioscience, University of the Western Cape, Private Bag X17, Bellville 7530, South Africa; ghughes@uwc.ac.za

2 Department of Science Technology, Biochemistry Unit, The Federal Polytechnic P.M.B.5351, Ado Ekiti 360231, Nigeria

3 Department of Botany, University of Fort Hare, Private Bag X1314, Alice 5700, South Africa; ccupido@ufh.ac.za

4 Phytomedicine and Phytochemistry Group, Oxidative Stress Research Centre, Department of Biomedical Sciences, Faculty of Health and Wellness Sciences,

Cape Peninsula University of Technology, P.O. Box 1906, Bellville 7535, South Africa; oguntibejuo@cput.ac.za

5 Department of Anatomy and Cellular Biology, College of Medicine and Health Sciences, Khalifa University, Abu Dhabi P.O. Box 127788, United Arab Emirates

* Correspondence: 3865115@myuwc.ac.za (K.A.A.); okobi.ekpo@ku.ac.ae (O.E.E.); Tel.: +27-839-612-040 (K.A.A.); +971-2-312-4912 (O.E.E.)

check for

updates

Citation: Akinyede, K.A.; Cupido, C.N.; Hughes, G.D.; Oguntibeju, O.O.; Ekpo, O.E. Medicinal Properties and In Vitro Biological Activities of Selected Helichrysum Species from South Africa: A Review. Plants 2021, 10, 1566. https://doi.org/10.3390/ plants10081566

Academic Editors:

Mariangela Marrelli and Luigi Milella

Received: 13 June 2021

Accepted: 8 July 2021

Published: 30 July 2021

Publisher's Note: MDPI stays neutral with regard to jurisdictional claims in published maps and institutional affiliations.

Copyright: (c) 2021 by the authors. Licensee MDPI, Basel, Switzerland. This article is an open access article distributed under the terms and conditions of the Creative Commons Attribution (CC BY) license (https:// creativecommons.org/licenses/by/ $4.0 /)$.

\begin{abstract}
The genus Helichrysum Mill comprises hundreds of species that are mostly flowering perennial shrubs. Some of these plants that belong to the Helichrysum species are used in traditional medicine to treat cough, back pain, diabetes, asthma, digestive problems, menstrual pain, chest pain, kidney disorders, skin disorders, wounds, open sores, among other conditions, but, only a few scientific studies are reported in the literature with sufficient information that validates the acclaimed folkloric benefits of these plants. This review, therefore, provides a comprehensive update of the available information on the cytotoxicity, genotoxicity, anti-proliferative, anti-bacterial, antifungal, anti-viral, anti-HIV, anti-malarial, anti-ulcerogenic, anti-tyrosinase, anti-inflammatory, and anti-oxidant activities of selected Helichrysum species of interest: H. petiolare, H. cymocum, H. foetidum, and H. pandurifolium Schrank, using scientific databases as well as electronic and print sources. The ethnobotanical and morphological characteristics as well as the phytochemical composition and biological activities of these plants are elucidated. The scientific rationale for their current use is discussed based on the evidence in the literature. This review highlights the putative use of the Helichrysum species as a reliable source of bioactive compounds for the production of standard commercial drugs to treat many ailments, including those reported in folkloric uses. Further research on the many plants in the genus Helichrysum is recommended to explore their economic importance both as edible crops and medicinal botanicals.
\end{abstract}

Keywords: medicinal plants; phytochemicals; pharmacological actions; Helichrysum species

\section{Introduction}

The genus Helichrysum Mill comprises distinctively of aromatic herbs and shrubs of the family Asteraceae. It has a worldwide distribution but is mainly found in Africa, with its highest diversity in South Africa, where approximately 245 of the 500 known species occur. Other areas of Helichrysum diversity include Europe, southwestern Asia, South India, Sri Lanka, Turkey, and Australia. For ease of identification, the southern African species are divided into 30 informal groups [1].

Plants of the Helichrysum genus have been in use for more than 2000 years for various folkloric purposes. The flowers of some members of this genus have a unique bright-yellow color that depicts their Greek language origins: "helios" and "chryos" which mean "sun" 
and "gold" respectively. In folkloric medicine, some Helichrysum plant parts are either consumed as teas or prepared as "burnt offering" smoke to disinfect the abodes of sick patients and to appeal for blessings from the ancestors in indigenous traditional practices [2]. In general, plants of this genus are known to be used in traditional medicine for the treatment of many ailments, including liver disorders, gall bladder complications, cystitis, jaundice, stomach pain, allergies, infections, colds, cough, skin infections, inflammation, menstrual pain, asthma, arthritis, insomnia, diabetes mellitus, and for wound healing [3-7], most commonly, the scented leaves and flowers.

The therapeutic properties of the Helichrysum species are often attributed to their different constituent phytochemicals, especially the essential oils [8,9]. In addition to the essential oils, plants in this species also contain such phytochemicals as terpenoids, phenolics and oxygenated compounds as secondary metabolites, including flavonoids, chalcones, phenolic acids, terpenes and essential oils, pyrone, benzofurans, and phloroglucinols [10]. Thus, these plants are potential reservoirs of bioactive compounds for drug discovery and development. Hitherto, only limited biological effects of the Helichrysum phytochemicals have been reported including, the antioxidant, antifungal, anti-inflammatory, anti-bacterial, hepatoprotective, anti-proliferative and anti-diabetic activities [7,11-13].

So far, only a few of the many Helichrysum species have been studied; the best known Helichrysum species used traditionally to treat different ailments are H. cymosum, H. odoratissimum, $H$. petiolare and $H$. nudifolium. Only limited information is available in the literature on these plant species on their ornamental, industrial and pharmaceutical applications [14]. Thus, in this review, peer-reviewed information on Helichrysum petiolare Hilliard \& B. L Burtt, Helichrysum cymosum (L.) D.Don, Helichrysum foetidum (L.). Moench and Helichrysum pandurifolium Schrank from South Africa will be elaborated, including their botanical, ethnopharmacological, phytochemical and bio-scientific profiles.

\section{Research Methodology}

The keywords relevant to this review, including "Helichrysum species" "Helichrysum petiolare Hilliard \& B. L Burtt", "Helichrysum cymosum (L.) D. Don", "Helichrysum foetidum (L). Moench", "Helichrysum pandurifolium Schrank", "cytotoxicity", "anti-genotoxicity", "anti-proliferative", "anti-bacterial", "anti-fungal", "anti-viral", "anti-malarial", "antiulcerogenic", "anti-tyrosinase", "anti-inflammatory", "antioxidant", "phytochemicals", "ethnopharmacology" and "essential oil" were searched for, using different databases including Sci Finder, ISI Web of Knowledge, Science Direct, Google Scholar, PubMed, Scopus, Wiley Online Library and Springer; while online theses, dissertations, and other print materials also provided important information on the traditional use, bioactive phytochemical compositions, biological and pharmacological actions, as well as leads on relevant gaps in research and future directions.

\section{Helichrysum petiolare and Its Biological Activities}

Helichrysum petiolare (H. petiolare) is commonly referred to as "Silverbush everlasting plant", and called "kooigoed" in the Afrikaans language of South Africa. This plant is a shrub with gray or silver-gray hair covering the aromatic round-shaped leaf, while its flowers are whitish-creamy [15]. H. petiolare is used in South African traditional medicine to treat fever, catarrh, cold, cough, menstrual disorders, kidney-related infections, chest problems, high blood pressure, and erectile dysfunction. In addition, the decoction of the leaves of the plant is used in traditional beauty therapy to refine skin texture/looks and for wound healing [16]. The known phytochemicals present in H. petiolare include phenols, flavonoids, and anthocyanins, the extract and its essential oil constituents were reported to show activity against Gram-positive and Gram-negative bacteria [17]. Other biological activities of this plant are discussed below. 


\subsection{Cytotoxicity/Anti-Proliferative Activity of H. petiolare}

The in vitro cytotoxic effects of the chloroform and methanol leaf and stem extracts of H. petiolare (1:1 solvent ratio) on transformed kidney epithelial (Graham's) cells, breast cancer cells (MCF-7) and brain cancer (SF-268) cells were studied using the sulforhodamine B (SRB) assay and the results showed percentage growth inhibition of 59\%,33\% and $76 \%$ for the Graham's, MCF-7, and SF-268 cell lines, respectively [18]. In another study, B16F10 mouse melanoma cells and MeWo human skin melanoma cells were treated with the methanol extract of $H$. petiolare, and the cytotoxicity and cell cycle analysis showed a dose-dependent reduction in cell viability or proliferation, as well as S-phase and M-phase cell cycle arrest, reflecting pro-apoptotic effects.

\subsection{Anti-Bacterial Activity of H. petiolare}

The anti-bacterial activities of nine Helichrysum species of South African origin, including H. petiolare, have been reported in such bacterial strains as Escherichia coli, Yersinia enterocolytica, Klebsiella pneumomiae (Gram-positive) and Staphylococcus aureus and Bacillus cereus (Gram-negative), using disc diffusion assay, with the standard drug neomycin as control [19]. When compared with the control, the methanol and acetone extracts of $H$. petiolare showed significant activities against $S$. aureus and B. cereus strains while the essential oils showed no activity against these two bacterial strains. The zone of inhibition is a uniformly circular area on an antibiotic dish that has no bacterial growth [20]. In the study under reference, the inhibition zone values ranged between $2.5 \mathrm{~mm}$ to $9.0 \mathrm{~mm}$ in the methanol and acetone extract-treated dishes compared with the $6 \mathrm{~mm}$ zone of inhibition in the standard drug. The Gram-positive bacteria were unaffected following treatment with the essential oil as well as the methanol and acetone extract of $H$. petiolare. Furthermore, the minimum inhibitory concentration (MIC) assay was used as a confirmatory test for the disc diffusion assay, and the results of this assay showed much improved activity for both the methanol and acetone extracts $(<0.25 \mathrm{mg} / \mathrm{mL})$ of $H$. petiolare when compared with the standard drug ciprofloxacin $\left(0.31 \times 10^{-3} \mathrm{mg} / \mathrm{mL}\right)$. However, the MIC assay showed a relatively low activity of the essential oil treatment $(8 \mathrm{mg} / \mathrm{mL})$ on the $S$. aureus bacterial strain [19].

In another study, Lourens and co-workers reported on the anti-bacterial effects of the methanol and chloroform (1:1 solvent ratio) extracts of $H$. petiolare on five bacterial strains, namely B. cereus, S. aureus, S. epidermidis, (Gram-positive), K. pneumomiae, and P. aeruginosa (Gram-negative), with ciprofloxacin as the positive control. The results showed minimum anti-bacterial effects against $S$. aureus and B. cereus with a MIC value of $4 \mathrm{mg} / \mathrm{mL}$ and $2 \mathrm{mg} / \mathrm{mL}$ respectively, compared to the control. However, no anti-bacterial activity was recorded against the remaining bacterial strains in the 96-well microplate assay [21].

\subsection{Anti-Inflammatory Activity of H. petiolare}

Louren and co-workers investigated the anti-inflammatory properties of the essential oil of $H$. petiolare using the 5-lipoxygenase assay, and the half-maximal inhibitory concentration $\left(\mathrm{IC}_{50}\right)$ value of $23.05 \pm 0.57 \mu \mathrm{g} / \mathrm{mL}$ was obtained for the varying concentrations of hydro-distilled essential oils, indicating potent anti-inflammatory effects. In comparison, the positive control had an $\mathrm{IC}_{50}$ value of $5.0 \pm 0.50 \mu \mathrm{g} / \mathrm{mL}$ while the methanol and acetone extract of $H$. petiolare showed no anti-inflammatory activity, with an $\mathrm{IC}_{50}$ value greater than $100 \mu \mathrm{g} / \mathrm{mL}$ [21].

\subsection{Anti-Fungal Activity of $\mathrm{H}$. petiolare}

Three strains of human fungi namely, Cryptococcus neoformanas, Candida albicans and Alternaria alternate, were evaluated using the disc diffusion assay. The results showed that only the acetone extract of $H$. pertiolare showed moderate anti-fungal activity against C. albican compared with the standard drug Nystatin. In contrast, the essential oil and methanol extract had no anti-fungal activity in the three fungal strains tested [21]. 


\subsection{Anti-Oxidant Activity of H. petiolare}

A slight modification of the 1,1 diphenyl -2- picrylhydrazyl (DPPH) free radical scavenging assay [20] was used to determine the anti-oxidant activity of the extracts of H. petiolare, in reference to the ascorbic acid standard. The results of treatment with the $\mathrm{IC}_{50}$ values of $44.28 \mu \mathrm{g} / \mathrm{mL}, 28.70 \mu \mathrm{g} / \mathrm{mL}$ and $2.5 \mu \mathrm{g} / \mathrm{mL}$ of the acetone and methanol extracts as well as the ascorbic acid standard, respectively, showed that more than $50 \%$ of the free radicals was inhibited or neutralized.

\subsection{Antigenotoxicity Activity of $\mathrm{H}$. petiolare}

The results from one study showed genotoxic effects of the methanol extracts of H. petiolare on normal Vero cells at concentration ranges of $12.5-200 \mu \mathrm{g} / \mathrm{mL}$, using the micronucleus assay [22]. In another study, the $90 \%$ methanol and dichloromethane (DCM) extracts of $H$. petiolare were screened for aflatoxin $B_{1}$-induced mutagenicity using the bacteria-based genotoxic Ames and Vitotox assays [23]. The methanol extract showed significant dose-dependent anti-mutagenic activity against S. typhimurium TA100 and TA 98 while the DCM extract had moderate anti-mutagenic effects against $S$. typhimurium TA 100 and more severe effects against $S$. typhimurium TA 98 . Cancer remains a global disease today with high mortality and morbidity rate. Mutagens are known to promote the pathogenesis of most cancers via gene mutation and chromosomal aberration and anti-mutagens are known to prevent chromosomal translocation, deletion and inversion [22,23]; hence the use of H. petiolare extracts as food supplements could serve as potential carcinoprotection agents, especially cancers induced by aflatoxin-producing fungi, in poorly-processed food crops.

\subsection{Anti-Tyrosinase Activity of H. petiolare}

A number of skin disorders are known to be promoted by anomalies in such implicated enzymes as tyrosinase and elastase, in the face of damaging free radical effects on the skin [24]. Therefore, compounds that inhibit such enzymes (e.g., tyrosinase inhibitors) could potentially be very useful in the cosmetic industry to prevent skin aging and other undesirable skin conditions $[25,26]$. H. petiolare plant extracts have been investigated for their tyrosinase inhibition activities (25), and results obtained showed moderate tyrosinase inhibition values of $44.3 \%$ and $59.2 \%$ at $50 \mu \mathrm{g} / \mathrm{mL}$ and $200 \mu \mathrm{g} / \mathrm{mL}$ concentrations respectively, using kojic acid as the reference control [25]. The results obtained tend to suggest that phytochemicals from the extracts of $H$. petiolare could inhibit free radical accumulation and modulate tyrosinase activity.

In another study, treatment with the ethanol extract of $H$. petiolare was found to be nontoxic to human dermal fibroblast (MRHF) cells using the Hoechst 3342/propidium iodide stain and resulted in decreased ROS and NO production following lipopolysaccharideinduced damage in the RAW 246.7 cell line. Additionally, weak inhibitory effects of the extract on the enzymes of collagenase, elastase and tyrosinase at various concentrations was reported in another study, compared to the positive control. In addition, this plant extract effectively inhibited protein glycation, indicating its potential use as an anti-aging agent for the skin [27].

\section{Helichrysum cymosum and Its Biological Activities}

Helichrysum cymosum (H. cymosum) is a plant endemic to South Africa and known commonly as "gold carpet" or "yellow-tipped strawflower" in English. Its local South African names include "goue tapyt" (in Afrikaans) and "impehho" (in isiXhosa). This plant is widely distributed in the Eastern Cape, KwaZulu-Natal, and Western Cape Provinces, and grows as a short, wooly shrub with grayish silver leaves and bright yellow-colored flowers in flat heads. This species is divided into two subspecies, namely the H. cymosum subsp. cymosum and H. cymosum subsp. calvum Hilliard [28,29], with distinct characteristics in the flowers, fimbrils, ovary, pappus, and plant length [29]. Traditionally, the aerial parts, leaves, roots, and leaves of this plant are used to treat different ailments ranging from cough, catarrh, colds, headache, menstrual pain, fever, wounds, flatulence, pulmonary problems, 
skin infections, pertussis vomiting as well as to improve immunity, and appetite $[15,29]$. The reported biological and pharmacological activities of H. cymosum include anti-bacterial, anti-fungal, anti-inflammatory, anti-malarial, anti-oxidant, and cytotoxic effects [15,29], some of which are briefly discussed below.

\subsection{Cytotoxicity of $H$. cymosum}

Vuuren et al. investigated the toxicity of the essential oil and acetone extract of $H$. cymosum as well as one of its isolated compounds, helihumulone on the transformed kidney epithelial cell line, using the tetrazolium-based cell proliferative or viability assay (MTT) [30]. The results showed that the essential oil was the most toxic extract, with an $\mathrm{IC}_{50}$ value of $17.47 \pm 33.0 \mu \mathrm{g} / \mathrm{mL}$ compared to $172.2 \pm 10.08 \mu \mathrm{g} / \mathrm{mL}$ for the acetone extract and $57.05 \pm 3.04 \mu \mathrm{g} / \mathrm{mL}$ for helihumulone, respectively. In another study, the cytotoxic effects of $H$. cymocum on the kidney Vero cell line were evaluated using the XTT assay with varying concentrations of different solvent extracts of the plant: 3.13 , $6.25,12.50,25.00,50.00,100.00,200.00$ and $400.00 \mu \mathrm{g} / \mathrm{mL}$. These results showed that compared to the positive control Zearlenone, with an $\mathrm{IC}_{50}$ value of $1.33 \pm 0.32 \mu \mathrm{g} / \mathrm{mL}$, the chloroform extract $\left(\mathrm{IC}_{50}\right.$ value $36.52 \pm 0.27 \mu \mathrm{g} / \mathrm{mL}$ ) was more toxic to the Vero cells than the methanol-water (50\% water/methanol and 50\% chloroform) extract with an $\mathrm{IC}_{50}$ value $59.74 \pm 0.14 \mu \mathrm{g} / \mathrm{mL}[31]$.

\subsection{Anti-Oxidant Activity of H. cymosum}

Francois (2016) investigated the anti-oxidant capacity of the essential oils isolated from $H$. cymosum leaves using the 1, 1 diphenyl 1- picrylhydrazyl (DPPH) assay. Results obtained showed that $50 \%$ free radical scavenging activity was achieved by the $6.3 \mathrm{~g} / \mathrm{L}$ concentration of this plant compared to the same effects by the $7.0 \mathrm{mg} / \mathrm{L}$ concentration of the positive control, butylated hydroxytoluene (BHT), a known compound used as a food anti-oxidant additive [29]. Thus, the extract of this plant had more anti-oxidant effects than BHT, indicating potential use as food additives. No other anti-oxidant studies involving $H$. cymosum were found in the literature at the time of writing this review, hence more studies are recommended.

\subsection{Anti-Malarial Activity of H. cymocum}

Vuuren et al. reported on the anti-plasmodium activity of the acetone crude extract, the essential oil, and the isolated compound helihumulone from $H$. cymocum on the falciparum parasite, relative to the effects of two standard anti-malaria drugs (quinine and chloroquine). The results from the G3-H hypoxanthine incorporation assay showed that when compared to the two standard anti-malarial drugs, quinine ( $\mathrm{IC}_{50}$ value $0.13 \pm 0.04 \mu \mathrm{g} / \mathrm{mL}$ ) and chloroquine $\left(\mathrm{IC}_{50}\right.$ value $\left.0.09 \pm 0.02 \mu \mathrm{g} / \mathrm{mL}\right)$, the essential oils had the least $\mathrm{IC}_{50}$ value $(1.25 \pm 0.77 \mu \mathrm{g} / \mathrm{mL})$ followed by helihumulone $(14.89 \pm 1.88 \mu \mathrm{g} / \mathrm{mL})$ and then the acetone crude extract $(60.76 \pm 2.83 \mu \mathrm{g} / \mathrm{mL})$. Considering the relatively low $\mathrm{IC}_{50}$ value of the essential oils of $H$. cymocum, their potential use as natural sources of anti-malarial treatment agents is plausible [30].

\subsection{Anti-Fungal Activity of H. cymocum}

The anti-fungal activity of the essential oil and acetone extract of H. cymocum as well as the isolated compound, helihumulone against $C$. neoformans and C. albicans was investigated using the microdilution technique, with a potent anti-fungal agent amphotericin $B$ as the positive control. The MIC values used ranged from $0.03-4.0 \mathrm{mg} / \mathrm{mL}$, and the results showed that the $0.03 \mathrm{mg} / \mathrm{mL}$ and $0.063 \mathrm{mg} / \mathrm{mL}$ MICs of the helihumulone were the most potent against $C$. neoformans and $C$. albicans [32]. Another study on the anti-fungal activity of the isolated essential oils of H. cymocum showed that over $50 \%$ zone of inhibition was achieved against Penicillium oxalicum while a $6 \mathrm{~mm}$ to $9 \mathrm{~mm}$ area of inhibition was reported for C. albicans $[33,34]$. 


\subsection{Anti-Bacterial Activity of H. cymocum}

Bougatsosa et al. reported on the anti-bacterial activities of the essential oils of H. cymocum against the Gram-positive bacteria S. aureus and S. epidermis as well as four Gram-negative bacteria, E. coli, Enterobacter cloacae, K. pneumoniae and Pseudomonas aeruginosa. The MIC results from the dilution technique showed that the essential oils of H. cymocum were not sensitive (completely inactive) to all the bacteria strains tested when compared to the essential oils of a closely-related plant species H. fulgidum (L.) Wild, which have been reported to be highly sensitive to the same bacterial strains tested [34]. Similar studies by Sindambiwe et al. showed that the $80 \%$ ethanol extract of $H$. cymocum was not sensitive to the bacteria Proteus vulgaris, E. coli, K. pneumoniae, P. aeruginosa, Salmonella paratyphi, B. cereus, Mycobacterium fortuitum and S. aureus, whereas Streptococcus pyogenes showed a MIC value of $5 \mathrm{mg} / \mathrm{mL}$ which indicates some sensitivity [35]. The results of another anti-bacterial activity study using the disc diffusion assay showed a zone of inhibition value of $7 \mathrm{~mm}$ and $5 \mathrm{~mm}$ respectively for $S$. aureus, $8 \mathrm{~mm}$ and $5 \mathrm{~mm}$ respectively for $B$. cereus, and no inhibition by the essential oils [32]. In yet another study, the isolated compound helihumulone, was found to have the highest anti-bacterial activity against the bacteria Enterococcus faecalis, B. cereus, B. subtilis, S. aureus, P. aeruginosa, E. coli, Y. enterocolitica, and K. pneumonia at the concentration range of $0.02-0.12 \mathrm{mg} / \mathrm{mL}$, using the p-iodo nitro tetrazolium (INT) microplate method, when compared with the essential oil $(1.0-8.0 \mathrm{mg} / \mathrm{mL})$ and acetone extract $(0.1-0.3 \mathrm{mg} / \mathrm{mL})$ of H. cymocum. The acetone extract activity was reported to be six times more than that of the essential oils [33].

\subsection{Anti-Inflammatory Activity of H. cymocum}

Standford and co-workers investigated the inhibitory effects of the ethanol and aqueous extracts of $H$. cymocum to prostaglandin, a known marker of inflammation, using the in vitro cyclooxygenase assay. The results showed that, whereas the standard antiinflammatory drug indomethacin showed $60 \%$ inhibition, the aqueous extract showed $52 \%$ and the ethanol extract showed $100 \%$ inhibitory activity [36]. In addition, other related plant species like Helichrysum excisum and Helichrysum felinum were reported to exhibit anti-inflammatory properties; the acetone extract and essential oil from H. excisum showed anti-inflammatory properties at $\mathrm{IC}_{50}$ concentrations of $35.09 \pm 1.12 \mu \mathrm{g} / \mathrm{mL}$ and $27.62 \pm 0.43 \mu \mathrm{g} / \mathrm{mL}$ respectively, using the 5-lipoxygenase assay, while the anti-inflammatory properties reported for the acetone extract and essential oil from $\mathrm{H}$. felinum, occurred at $\mathrm{IC}_{50}$ concentrations of $38.72 \pm 2.94 \mu \mathrm{g} / \mathrm{mL}$ and $22.87 \pm 7.59 \mu \mathrm{g} / \mathrm{mL}$ respectively, in comparison with control with $\mathrm{IC}_{50}$ of $5.00 \pm 0.50 \mu \mathrm{g} / \mathrm{mL}$ [37].

\subsection{Anti-Viral Activity of H. cymocum}

The virucidal activity of the ethanol extract of $H$. cymocum against selected viruses was studied using the $50 \%$ endpoint titration technique (EPTT). This assay involves the determination of virus titer reduction in the presence of two-fold dilutions of test compounds on monolayers of cells grown in plastic or glass Petri dishes [38]. The results obtained showed that the extract was effective against the simplex virus type 1 (HSV1), the measles virus strain Edmonston A (MV-EA) as well as the Semliki forest virus $A_{7}$ (S.F. $A_{7}$ ) [35]. In addition, the anti-viral bioactivity of the methanol/water and chloroform (50\% water/methanol and $50 \%$ chloroform) extracts of the aerial parts of H. cymocum were investigated in one study using colorimetric cell-based, a cytopathic effect inhibition assay. The results showed cytopathic effects against Vero cells at a final toxic concentration of $400 \mu \mathrm{g} / \mathrm{mL}$, compared with the positive control acyclovir with anti-viral activity of $0.75 \mu \mathrm{g} / \mathrm{mL}$ [31].

\section{Helichrysum foetidum and Its Biological Activities}

H. foetidum is a robust herb commonly referred to as the stinging starflower with a characteristic pungent smell. Its leaves are elliptic, sparsely hairy, white-woolly, and are arranged in groups at the base of the stem while its many flower heads are borne in broad, leafy spreading umbrella-like inflorescences [39]. This plant is native to South Africa and 
has since been introduced to other parts of the world, including Spain, Portugal, and Southern Brazil [40]. H. foetidum is used in African tradomedical practices to induce a trance, mainly due to its hallucinatory effects. It is also used for the treatment of wounds, for dressing the circumcised penis in traditional ceremonies, for infected sores, for menstrual pains, herpes, eye infection, influenza, among other ailments [39]. The chemical composition of $H$. foetidum includes diterpenoid, Kaur-16-en-18-oic acid, flavonoid, apigenin 7,4 O-dihydroxy-5-methoxy-flavanone, apigenin 7-O- $\beta$-D- glucoside and 6-methoxy-2', 4,4-trihydroxy-chalcone helichrysetins, as well as glucosylated helichrysins [41]. Its biological activities include anti-bacterial [42], anti-fungal [43], anti-viral [35], antioxidant, anti-ulcerogenic, and cytotoxic effects [43].

\subsection{Cytotoxicity of $H$. foetidum}

The in vitro cytotoxic effects of the isolated compounds of $H$. foetidum on the human prostate cancer cell line (PC-3) were evaluated using the XTT assay. These compounds were found to have no effects on PC-3 viability at the concentrations. It was reported that the compound reduced the viability of cancer cells and induced apoptosis at the concentrations of $50 \mathrm{nM}$ or $50 \mu \mathrm{M}$ of the isolated compound [42]. In another study, the transformed human kidney epithelial (Graham's) cells, MCF-7 breast adenocarcinoma cells, and SF-268 glioblastoma cells were reported to be sensitive to the leaf and stem extracts of chloroform and methanol (solvent ratio $1: 1)$, with a significant reduction in cell viability $(24.9 \%)$ in MCF-7 cells, at a concentration of $0.1 \mathrm{mg} / \mathrm{mL}$ of the extract [18].

\subsection{Anti-Ulcerogenic Properties of H. foetidum}

Malolo et al. reported on the potential of the methanol extract and the isolated compounds from $H$. foetidum, to inhibit the enzyme protease, through the in vitro protease pepsin inhibition assay known as the fluorescence resonance energy transfer (FRET) assay [43]. Pepsin is the main acid protease of the stomach and is implicated in peptic ulcer disease, reflux oesophagitis, and excessive stomach acid secretion, although Helicobacter pylori bacteria are also involved in the pathogenesis of most gastric diseases. Following treatment with the methanol extract of $H$. foetidum, the FRET assay showed $17.8 \%, 35.6 \%$ and $37.6 \%$ inhibitory activity against pepsin at the concentrations of $10 \mu \mathrm{g} / \mathrm{mL}, 25 \mu \mathrm{g} / \mathrm{mL}$ and $50 \mu \mathrm{g} / \mathrm{mL}$, respectively; however, no action was detected against subtilisin, a known alkaline protease $[43,44]$. Furthermore, out of the six isolated compounds tested in this study, only apigenin-7- $\beta$-D-glucoside and $6^{\prime}$ methoxy-2 ${ }^{\prime}, 4$ dihydroxychalcone- $4^{\prime}-O-\beta$-D-glucoside showed moderate inhibition range of $37.4 \%$ to $46.3 \%$ at $50 \mu \mathrm{g} / \mathrm{mL}$ concentration [43].

\subsection{Anti-Bacterial Activity of H. foetidum}

Steenkamp et al. (2014) investigated the anti-bacterial activity of the methanol, and aqueous extracts of $H$. foetidum against $S$. aureus, S. pyrogenes, E. coli, and P. aeruginosa, and the results showed a MIC value of not more than $4 \mathrm{mg} / \mathrm{mL}$ in all the bacterial strains tested [45]. In addition, the anti-bacterial activity of the methanol extract and six isolated compounds from $H$. foetidum against B. subtilis bacteria was evaluated in another study, using a fluorescence-based anti-bacterial inhibition assay [43]. The results obtained showed MIC values of $85.4 \%$ and $21.8 \%$ for the methanol extract, at the concentration range of $1.0 \mathrm{mg} / \mathrm{mL}$ and $0.1 \mathrm{mg} / \mathrm{mL}$ respectively, while the isolated compounds displayed growth inhibition in the range of $75.0 \%$ to $85.0 \%$.

\subsection{Anti-Fungal Activity of $H$. foetidum}

Cladosporium cucumerrinum is a known fungus that causes diseases in plants, leading to reduced crop yield. The in vitro anti-fungal activity of the methanol extract and six isolated compounds from $H$. foetidum against this pathogen was reported [45]. The concentrations of $50 \mu \mathrm{g} / \mathrm{cm}, 100 \mu \mathrm{g} / \mathrm{cm}, 200 \mu \mathrm{g} / \mathrm{cm}$ and $400 \mu \mathrm{g} / \mathrm{cm}$ of the methanol extract of Helichrysum foetidum used in a bioautograpy assay on silica gel plates, indicated that zones of growth inhibition against the fungus were well developed on bioautograpy plate, showing a 
significant anti-fungal property [45]. All the six isolated compounds showed growth inhibition against C. cucumerrinum in the range of $70 \%$ to $56 \%$ at $1.0 \mathrm{mg} / \mathrm{mL}$ concentrations in the assay [45].

\subsection{Anti-Oxidant Activity of H. foetidum}

Bruno et al. reported the anti-oxidant activity of the methanol extract of $H$. foetidum using an array of in vitro assays [46], including the 2-2' azinobin-3-ethlbenzothiazoline-6sulphonic acid (ABTS), 1,1-diphenyl-2-picrylhydrazyl (DPPH) radical-scavenging, and the $\beta$-carotene/linoleic acid assay. The anti-oxidant activity of the methanol extract of $H$. foetidum determined by the ABTS and DPPH assays, occurred at the $\mathrm{IC}_{50}$ concentrations of $0.5 \pm 0.1 \mu \mathrm{g}, 0.6 \pm 0.1 \mu \mathrm{g}$, and $1.5 \pm 0.3 \mu \mathrm{g}$ respectively, compared with the known antioxidant compounds, Trolox or BHT, used as the standards, with $\mathrm{IC}_{50}$ values of $1.3 \mu \mathrm{g}$ and $1.5 \mu \mathrm{g}$ respectively. On the other hand, the scavenging of hydrogen peroxide (HRPO) test, the superoxide anion scavenging (SAS) test and the hypochlorous acid scavenging (taurine) test showed anti-oxidant activity at $\mathrm{IC}_{50}$ concentrations of $15.0 \pm 2.0 \mu \mathrm{g}, 34.0 \pm 6.0 \mu \mathrm{g}$, and $24.0 \pm 3.0 \mu \mathrm{g}$ respectively. The anti-oxidant activity of medicinal plants is commonly attributed to the presence of phenols, flavonoids, flavanols, and oligomeric proanthocyanidins, which in this study, were quantified to be $580 \pm 87 \mathrm{mg} / \mathrm{g}, 460 \pm 69 \mathrm{mg} / \mathrm{g}$, $12 \pm 2 \mathrm{mg} / \mathrm{g}$, and $5 \pm 1 \mathrm{mg} / \mathrm{g}$ respectively, in the methanol extract of H. foetidum [46].

\subsection{Anti-Viral Activities of H. foetidum}

The $50 \%$ endpoint titration technique (50\% EPTT) was adopted by Sindambiwe et al. (1999) to evaluate the anti-viral activities of the aqueous and $80 \%$ ethanol extracts of the whole plant parts of H. foetidum. Virucidal activities against HSV1 and the Semliki Forest virus A7 (SFA7) were reported but not against the measles virus strain Edmonston A (MV-EA) and the vesicular stomatitis virus T2 (VSVT2) [35].

\section{Helichrysum pandurifolium Schrank and Its Biological Activities}

The common name of $H$. pandurifolium Schrank is Hottentotskruie or Hottentotskooigoed or fiddle leaf-strawflower, with the stem and leaf parts often prepared as infusions for the traditional treatment of such ailments as respiratory conditions, cough, heart conditions, kidney stones and other kidney-related conditions [10]. The plant is a tall, slender, looselybranched and soft shrub with orbicular-to-ovate leaves that abruptly narrow at a broad petiole-like base. The flowers are yellow, with the outer and inner parts of the involucre bracts being light-brown and white-pink, respectively. The apex of this herbal plant is sharp, while its fruits have a pappus with an array of feathery bristles $[14,40]$.

Currently, information on the phytochemicals and pharmacological actions of H. pandurifolium Schrank is scanty in the literature, a possible indication that this species is not well-studied scientifically.

\section{Common Phytochemicals Present in the Selected Helichrysum Species}

Phytochemicals refer to structurally diverse secondary metabolites or compounds that are produced by plants or non-pathogenic endophytic microorganisms in plants, to serve a protective role against any form of insults by pathogens (bacteria, fungi and viruses), through participation in the body's anti-oxidant defensive and protective mechanisms such as free-radical scavenging [47,48]. Phytochemicals, therefore, confer essential pharmacological or biological functions on medicinal plants. In 1967, phytochemical studies of the helichrysum genus were done, and the helichrysum dendroideum species was the first to be explored [49], leading to the identification of many chemical secondary metabolites. Scientific reports on 63 helichrysum species of South African origin have shown many isolated compounds, including acylphloroglucinol, humulone derivatives, flavonoids, 8-hyroxyflavonols, $\alpha$-pyrones, chalcone, and pyranochalcones $[37,50,51]$; essential oils, benzofurans, oxygenated compounds are present in the many species of this plant genus [10]. Representative of some of the compounds present in $H$. petiolare, $H$. cymosum, H. foetidum 
and H. pandurifolium Schrank are depicted in Figures 1-4. While the biological functions of the associated compounds including that of the essential oils are listed in Tables 1-5 in this review.<smiles>COc1cc(O)cc(O)c1C(=O)CCc1ccc(O)cc1</smiles>

6'-Methoxy-2',4, 4'-trihydroxychalcone<smiles>C=C1CC23CCC4C(C(=O)O)(CCCC42C)CCC1(O)CC3</smiles>

Kaur-16-en-18-oic acid<smiles>O=c1cc(-c2ccc(O)cc2)oc2cc(O)cc(O)c12</smiles>

Apigenin<smiles>O=c1cc(-c2ccc(O)cc2)oc2cc(OC3OC(CO)C(O)C(O)C3O)cc(O)c12</smiles>

Apigenin-7-O- $\beta$-D-glucoside<smiles>CCOc1cc(O)c(CC=C(C)C)c2c1C(=O)CC(c1ccc(O)cc1)O2</smiles>

7, 4'-dihydroxy-5-methoxy-flavanone<smiles>O=C(CCc1ccc(O)c(O)c1)OC1C(O)CC(O)(C(=O)O)C(OC(=O)CCc2ccc(O)c(O)c2)C1O</smiles>

4,5-Dicaffeoyl quinic acid<smiles>COc1cc(CCC(=O)O)ccc1O</smiles>

Ferulic acid<smiles>O=C(CCc1ccc(O)c(O)c1)OC1CC2(C(=O)O)CC(O)C(O)C1C2</smiles>

Chlorogenic acid<smiles>CC(C)C(C)CCC(C)C1CCC2C3=CCC4CC(O)CCC4(C)C3CCC21C</smiles>

Campest-7-en-3-ol

Figure 1. Structures of phytochemicals isolated from plants of Helichrysum foetidum. 
<smiles>CC1=C2C=C(C(C)C)CCC2(C)CCC1</smiles>

$\delta$-Selinene<smiles>CC(=CCO)CCCC(C)CCCC(C)CCCC(C)C</smiles>

Phytol<smiles>CC1=CCC(C(C)C)c2cc(C)ccc21</smiles>

$\alpha$-Calacorene<smiles>C=C1CCC2C(C1C)C2C1(C)CCC(O)(O)C1</smiles>

Spathulenol<smiles>CC1=CC2C(=C(C)CCC2C(C)C)CC1</smiles>

$\delta$-Cadinene<smiles>CCOc1ccc(C(O)CO)cc1O</smiles>

Phenol, 2-ethoxy-5-(1, 2-dihydroxyethyl)-<smiles>CC1CCC2C1C1C(CCC2(C)O)C1(C)C</smiles>

Ledol<smiles>CC1CCCC2(C)CCC3CC12OC3(C)C</smiles>

$\beta$-Hydroagarofuran<smiles>C=C(C)C1CCC(C)=C2CCC(C)C2C1</smiles>

$\alpha$-Bulnesene<smiles>C=C1CCC2C3CCC(C)C3C2C12CC2</smiles>

Alloaromadendrene

Figure 2. Structures of phytochemicals isolated from Helichrysum petiolare.

Table 1. Description of bioactivity of the compounds of Helichrysum cymosum.

\begin{tabular}{cc}
\hline Compounds & Biological Functions \\
\hline Helihumulone & anti-bacterial and anti-mycotic [15,52] \\
\hline (Z)- $\beta$-ocimene & Molluscidal and leshimanicidal agents [53] \\
\hline Trans-caryophyllene & Anti-malarial [15,36] \\
\hline 1, 8-cineole & Anti-inflammatory, antioxidant, anticancer, analgesic [54] \\
\hline$\alpha$-humulene & Anti-Proliferative [55] \\
\hline (E)- $\beta$-ocimene & Molluscidal and leshimanicidal agents [53] \\
\hline Caryophyllene oxide & Anti-malarial [15,36] \\
\hline$\beta$-caryophyllene & Anti-malarial [15,36] \\
\hline$\Delta$-3-carene & AChE inhibition, anti-inflammatory Anti-fungal [56,57] \\
\hline $\begin{array}{c}\text { 5-hydroxy-8-methoxy-7- } \\
\text { prenyloxyflavanone }\end{array}$ & Antiral [30] \\
\hline
\end{tabular}


<smiles>COC1(CC=C(C)C)C(=O)C(C(=O)CCc2ccccc2)=C(O)C(CC=C(C)C)=C1O</smiles>

Helihumulone<smiles>C=C1CCCC(C)CCC1C1CC1(C)C</smiles>

Trans-caryophyllene<smiles>CC1CCCC(C)(C)CCC1</smiles>

$\alpha$-Humulene

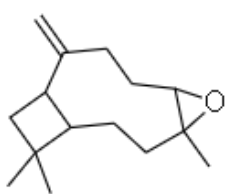

Caryophyllene oxide<smiles>C=CC(C)=CCC=C(C)C</smiles>

(Z)- $\beta$-Ocimene<smiles>CC(=O)OC1CC2CCC1(C)OC2(C)C</smiles>

1,8-Cineole<smiles>C=CC(C)=CCC=C(C)C</smiles>

(E)- $\beta$-Ocimene<smiles>C=C1CCCC(C)CCC1C1CC1(C)C</smiles>

$\beta$-Caryophyllene<smiles>CC1=CCC2C(C1)C2(C)C</smiles>

\section{$\Delta$-3-carene}

Figure 3. Structures of phytochemicals isolated from Helichrysum cymosum.

Table 2. Description of bioactivity of the compounds Helichrysum foetidum.

\begin{tabular}{|c|c|}
\hline Compounds & Biological Functions \\
\hline $6^{\prime}$-methoxy-2' $4,4^{\prime}$-trihydroxychalcone & Anti-bacterial, anti-fungal, anti-ulcerogenic [43] \\
\hline $6^{\prime}$-methoxy-2',4-dihydroxychalcone- $4^{\prime}$-O- $\beta$-D-glucoside & Anti-bacterial, anti-fungal, anti-ulcerogenic [43] \\
\hline Kaur-16-en-18-oic acid & Anti-bacterial, anti-fungal, anti-ulcerogenic [43] \\
\hline Apigenin & Anti-bacterial, anti-fungal, anti-ulcerogenic [43] \\
\hline Apigenin-7-O- $\beta$-D-glucoside & Anti-bacterial, anti-fungal, anti-ulcerogenic [43] \\
\hline 7,4'-dihydroxy-5-methoxy-flavanone & Anti-bacterial, anti-fungal, anti-ulcerogenic [43] \\
\hline 4,5-diacaffeoyl quinic acid & Anti-bacterial, anti-fungal, anti-ulcerogenic [43] \\
\hline Ferulic acid & $\begin{array}{l}\text { Anti-inflammatory, anti-oxidant, anti-diabetic, } \\
\text { anti-hypertensive [58] }\end{array}$ \\
\hline Chlorogenic acid & $\begin{array}{l}\text { Anti-oxidant, anti-inflammatory, Anti-bacterial, anti-mutagenic } \\
\text { and anti-cancer [59] }\end{array}$ \\
\hline Campest-7-en-3-ol & Anti-bacterial, antifungal, anti-ulcerogenic [43] \\
\hline
\end{tabular}




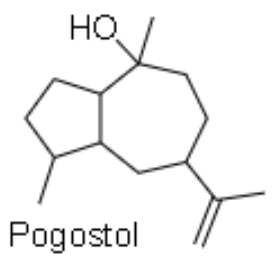<smiles>CC1CCC2C1C1C(CCC2(C)O)C1(C)C</smiles>

Viridiflorol<smiles>CCC(C)(O)CCC=C(C)CCC(C)C</smiles>

Germacrene d-4-ol<smiles>C=C(C)C1CCC2(C)CCCC(=C)C2C1</smiles>

$\beta$ - selinene

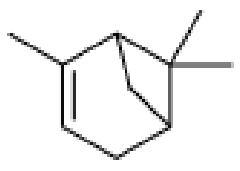

$\alpha$ - pinene<smiles>C=CC(=C)CCC=C(C)CC(C)=[Mg]</smiles>

Myrcene<smiles>C=C1CCC2CC1C2(C)C</smiles>

B-pinene<smiles>C=C(C)C1CC=C(C)CC1</smiles>

Limonene<smiles>Cc1ccc(C(C)CCCC(C)CCCC(C)C)cc1</smiles>

(E)-1(6,10-dimethylundec-5-en-2-y)-4-methYlbenzene

Figure 4. Structures of phytochemicals isolated from H. pandurifolium.

Table 3. Description of bioactivity of the compounds of Helichrysum petiolare.

\section{Compounds}

Alloaromadendrene $\delta$-Selinene

Phenol, 2-ethoxy-5- (1, 2-dihydroxyethyl) -

Phytol

\begin{tabular}{cc}
\hline Ledol & N/A \\
\hline$\alpha$-Calacorene & Anti-microbial, anti-oxidant [63] \\
\hline$\beta$-Hydroagarofuran & Anti-bacterial and anti-mycotic [15] \\
\hline Spathulenol & Anti-inflammatory, anti-nociceptive [64,65] \\
\hline$\alpha$-Bulnesene & Anti-platelet aggregation agent [66] \\
\hline$\delta$-Cadinene & Anti-malarial [67] \\
\hline
\end{tabular}

Anti-oxidant, anti-microbial, anti-convulsant, cytotoxic, anti-inflammatory [62]

\section{Biological Functions}

Anti-microbial, anti-viral, anti-diabetic, anti-inflammatory [60] anti-fungal [61]

N/A

Not available: N/A 
Table 4. Description of bioactivity of the compounds of H. pandurifolium.

\begin{tabular}{cc}
\hline Compounds & Biological Functions \\
\hline Viridiflorol & Anti-fungal, anti-bacterial [14] \\
\hline Pogostol & $\mathrm{N} / \mathrm{A}[14]$ \\
\hline$\alpha$-pinene & $\mathrm{N} / \mathrm{A}[14]$ \\
\hline$\beta$-pinene & $\mathrm{N} / \mathrm{A}[14]$ \\
\hline Aristolochene & $\mathrm{N} / \mathrm{A}[14]$ \\
\hline (E)-1(6,10-dimethylundec-5-en-2-yl)-4-methylbenzene & $\mathrm{N} / \mathrm{A}[14]$ \\
\hline Z- $\beta$-ocimene & $\mathrm{N} / \mathrm{A}[14]$ \\
\hline$\delta$-cadinene & $\mathrm{N} / \mathrm{A}[14]$ \\
\hline Germacrene d-4-ol & $\mathrm{N} / \mathrm{A}[14]$ \\
\hline 1,8 -cineole & $\mathrm{N} / \mathrm{A}[14]$ \\
\hline
\end{tabular}

Not available: N/A.

\section{Essential Oils Present in Selected Helichrysum Species}

Essential oils (EOs) are the condensed or concentrated hydrophobic liquids that contain volatile chemical compounds derived from plants. The variety of compounds in EOs depends on such factors as the plant species, plant part used (leaves, fruits, roots), harvest period, environmental conditions (land fertility, humidity, temperature) and the extraction technique employed [68].

One distinct characteristic of the helichrysum genus is its aromatic nature and most of the species in this genus have been reported to be rich in essential oils (EOs) containing many compounds [10]. Many EOs are prescribed as alternative medicine (in aromatherapy) based on the healing effects of their aromatic compounds [69]. Monoterpenes, sesquiterpenes and diterpenes are some of the broad groups of compounds present in the EOs of most plants, including the helichrysum genus; these compounds are largely responsible for the reported anti-fungal, anti-bacterial, anti-diabetic, anti-inflammatory, anti-ulcer, anti-cancer, anti-oxidant, anti-nociceptive, and anti-spasmodic properties associated with these plants. 
Table 5. The common phytochemical compounds present in the essential oils of selected Helichyrsum species.

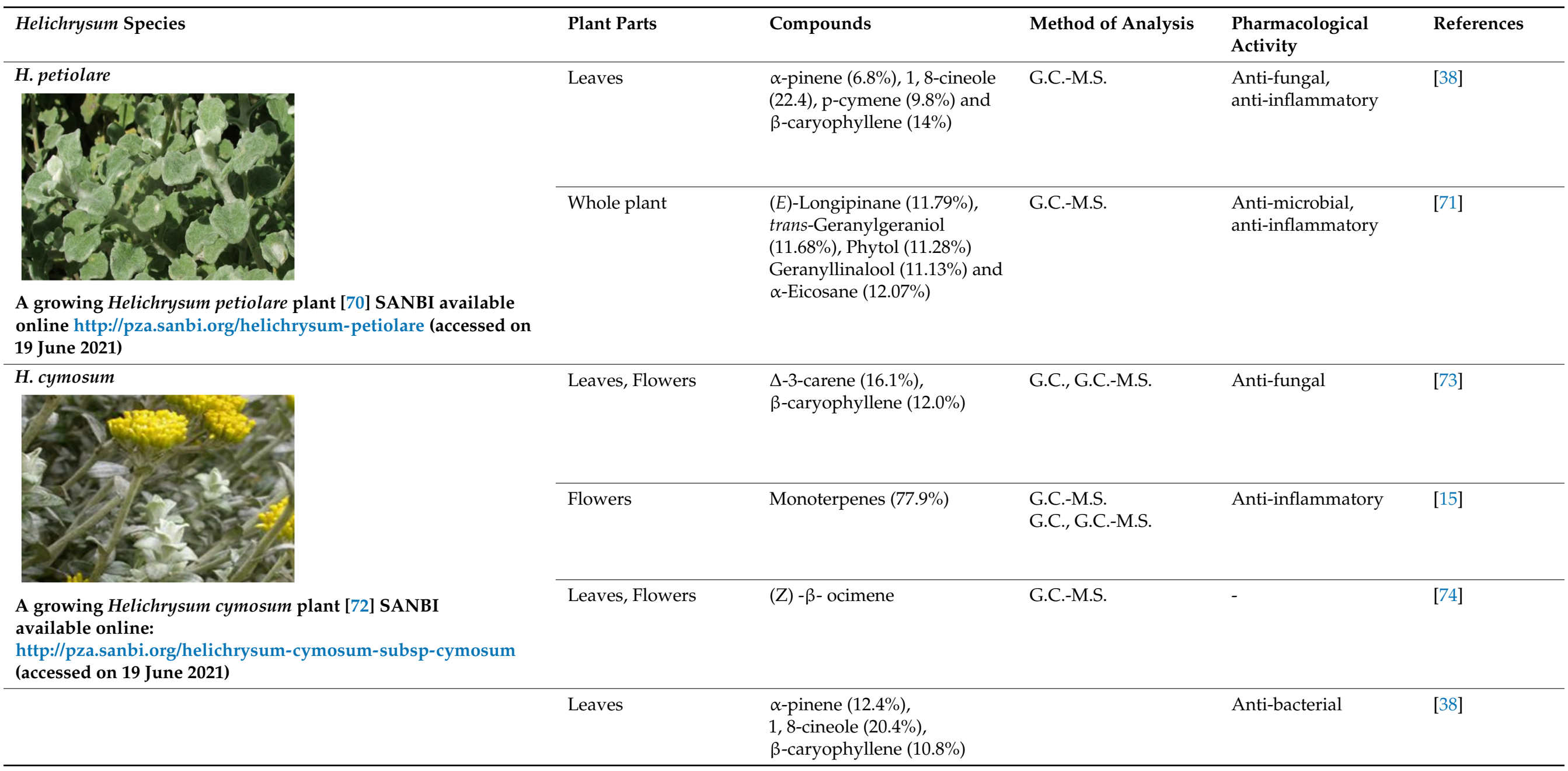


Table 5. Cont

\begin{tabular}{|c|c|c|c|c|c|}
\hline Helichrysum Species & Plant Parts & Compounds & Method of Analysis & $\begin{array}{l}\text { Pharmacological } \\
\text { Activity }\end{array}$ & References \\
\hline H. foetidum & Leaves, flower & $\begin{array}{l}\text { B-pinene }(3.1 \%), \\
\text { Trans-Sabiene hydrate }(1.8 \%), \\
\text { 4-terpineol }(3.1 \%), \\
\beta \text {-caryophyllene }(2.5 \%)\end{array}$ & G.C.-M.S. & $\begin{array}{l}\text { Anti-microbial } \\
\text { Anti-inflammatory }\end{array}$ & [75] \\
\hline \multicolumn{6}{|c|}{$\begin{array}{l}\text { A growing Helichrysum foetidum plant [39] SANBI available } \\
\text { online http://pza.sanbi.org/helichrysum-foetidum (accessed on } \\
19 \text { June 2021) }\end{array}$} \\
\hline H. pandurifolium & & $\mathrm{N} / \mathrm{A}$ & $\mathrm{N} / \mathrm{A}$ & $\mathrm{N} / \mathrm{A}$ & $\mathrm{N} / \mathrm{A}$ \\
\hline $\begin{array}{l}\text { A growing Helichrys } \\
\text { Available online: } \\
\text { https://www.inatural } \\
19 \text { June 2021) }\end{array}$ & & & & & \\
\hline
\end{tabular}




\section{Conclusions}

Plants belonging to the Helichrysum genus are a vital source of traditional medicines in many parts of the world, including South Africa. The many novel chemical compounds present in the extracts of these plants and their essential oils account for most of their pharmacological actions. This review highlighted the reported diversity of the Helichrysum genus and the ethnomedicinal and biological activities of some of its species. However, only limited scientific reports are available in the literature on some species, hence further multidisciplinary studies by botanists, chemists, ethnopharmacologists and medical scientists are required on all the plants in this genus, as they appear to be potential sources of useful bioactive medicinal compounds that could be exploited in the drug discovery and development value chain.

Author Contributions: Conceptualization: K.A.A., O.E.E., O.O.O. and C.N.C. Writing of the original draft: K.A.A.; Editing: K.A.A., O.E.E., O.O.O., G.D.H. and C.N.C.; Supervision: O.E.E., O.O.O. and G.D.H. All authors have read and agreed to the published version of the manuscript.

Funding: This research work received no external funding.

Institutional Review Board Statement: Not applicable.

Informed Consent Statement: Not applicable.

Data Availability Statement: Not applicable.

Acknowledgments: The authors acknowledge the support of the following institutions towards the completion of this review article: University of the Western Cape (UWC), Cape Town-South Africa; Cape Peninsula University of Technology (CPUT), Cape Town-South Africa; University of Fort Hare (UFH), Alice-South Africa; The Federal Polytechnic, Ado Ekiti-Nigeria; Khalifa University, Abu Dhabi-UAE.

Conflicts of Interest: The authors declare no conflict of interest.

\section{References}

1. Hillard, O. Flora of southern Africa. In Asteraceae; Leistner, O.A., Ed.; Botanical Institute of South Africa: Pretoria, South Africa, 1983; Volume 33, pp. 61-310.

2. Pooley, E. Mountain Flowers: A Field Guide to the Flora of the Drakensberg and Lesotho; Flora Publications Trust: Durban, South Africa, 2003.

3. Viegas, D.A.; Palmeira-de-Oliveira, A.; Salgueiro, L.; Martinez-de-Oliveira, J.; Palmeira-de-Oliveira, R. Helichrysum italicum: From traditional use to scientific data. J. Ethnopharmacol. 2014, 151, 54-65. [CrossRef]

4. Rigano, D.; Formisano, C.; Pagano, E.; Senatore, F.; Piacente, S.; Masullo, M.; Capasso, R.; Izzo, A.A.; Borrelli, F. A new acetophenone derivative from flowers of Helichrysum italicum (roth) don ssp. Ital. Fitoter. 2014, 99, 198-203. [CrossRef]

5. Czinner, E.; Lemberkovics, É.; Bihátsi-Karsai, E.; Vitányi, G.; Lelik, L. Composition of the essential oil from the inflorescence of Helichrysum arenarium (L.) Moench. J. Essent. Oil Res. 2000, 12, 728-730. [CrossRef]

6. Eroğlu, H.E.; Hamzaoğlu, E.; Aksoy, A.; Budak, Ü.; Albayrak, S. Cytogenetic effects of Helichrysum arenarium in human lymphocytes cultures. Turk. J. Biol. 2010, 34, 253-256.

7. Reidel, R.V.B.; Cioni, P.L.; Ruffoni, B.; Cervelli, C.; Pistelli, L. Aroma profile and essential oil composition of Helichrysum species. Nat. Prod. Commun. 2017, 12, 1934578X1701200931.

8. Harborne, J.B.; Turner, B.L. Plant Chemosystematics; Academic Press: London, UK, 1984.

9. Mari, A.; Napolitano, A.; Masullo, M.; Pizza, C.; Piacente, S. Identification and quantitative determination of the polar constituents in Helichrysum italicum flowers and derived food supplements. J. Pharm. Biomed. Anal. 2014, 96, 249-255. [CrossRef]

10. Akaberi, M.; Sahebkar, A.; Azizi, N.; Emami, S.A. Everlasting flowers: Phytochemistry and pharmacology of the genus Helichrysum. Ind. Crop. Prod. 2019, 138, 111471. [CrossRef]

11. Aslan, M.; Orhan, D.D.; Orhan, N.; Sezik, E.; Yeşilada, E. A study of antidiabetic and anti-oxidant effects of Helichrysum graveolens capitulums in streptozotocin-induced diabetic rats. J. Med. Food 2007, 10, 396-400. [CrossRef]

12. Hutchings, A.; van Staden, J. Plants used for stress-related ailments in traditional zulu, xhosa and sotho medicine. Part 1: Plants used for headaches. J. Ethnopharmacol. 1994, 43, 89-124. [CrossRef]

13. Najar, B.; Nardi, V.; Cervelli, C.; Mecacci, G.; Mancianti, F.; Ebani, V.V.; Nardoni, S.; Pistelli, L. Volatilome analyses and In Vitro antimicrobial activity of the essential oils from five South African Helichrysum species. Molecules 2020, 25, 3196. [CrossRef] 
14. Giovanelli, S.; De Leo, M.; Cervelli, C.; Ruffoni, B.; Ciccarelli, D.; Pistelli, L. Essential oil composition and volatile profile of seven Helichrysum species grown in italy. Chem. Biodivers. 2018, 15, e1700545. [CrossRef]

15. Lall, N.; Kishore, N. Are plants used for skin care in south africa fully explored? J. Ethnopharmacol. 2014, 153, 61-84. [CrossRef]

16. Serabele, K.; Chen, W.; Tankeu, S.; Combrinck, S.; Veale, C.G.; van Vuuren, S.; Chaudhary, S.K.; Viljoen, A. Comparative chemical profiling and antimicrobial activity of two interchangeably used 'imphepho'species (Helichrysum odoratissimum and Helichrysum petiolare). S. Afr. J. Bot. 2021, 137, 117-132. [CrossRef]

17. Lourens, A.; Van Vuuren, S.; Viljoen, A.; Davids, H.; Van Heerden, F. Antimicrobial activity and in vitro cytotoxicity of selected South African Helichrysum species. S. Afr. J. Bot. 2011, 77, 229-235. [CrossRef]

18. Sagbo, I.J.; Otang-Mbeng, W. Anti-proliferative and genotoxic activities of the Helichrysum petiolare Hilliard \& B.L. Burtt. Sci. Pharm. 2020, 88, 49 .

19. Ajiboye, A.E.; Ameen, M.T.; Adedayo, M.R. Antimicrobial activity and phytochemical screening of the fruit pulp of Dialium guineense (velvet tamarind) on some microbial isolates. J. Microbiol. Antimicrob. 2015, 7, 33-41. [CrossRef]

20. Di Mambro, V.M.; Azzolini, A.E.; Valim, Y.M.; Fonseca, M.J. Comparison of anti-oxidant activities of tocopherols alone and in pharmaceutical formulations. Int. J. Pharm. 2003, 262, 93-99. [CrossRef]

21. Lourens, A.; Reddy, D.; Başer, K.; Viljoen, A.; Van Vuuren, S. In Vitro biological activity and essential oil composition of four indigenous South African Helichrysum species. J. Ethnopharmacol. 2004, 95, 253-258. [CrossRef]

22. Makhuvele, R.; Matshoga, R.; Antonissen, R.; Pieters, L.; Verschaeve, L.; Elgorashi, E.E. Genotoxicity and antigenotoxicity of selected South African indigenous plants. S. Afr. J. Bot. 2018, 114, 89-99. [CrossRef]

23. Słoczyńska, K.; Powroźnik, B.; Pękala, E.; Waszkielewicz, A.M. Antimutagenic compounds and their possible mechanisms of action. J. Appl. Genet. 2014, 55, 273-285. [CrossRef]

24. Działo, M.; Mierziak, J.; Korzun, U.; Preisner, M.; Szopa, J.; Kulma, A. The potential of plant phenolics in prevention and therapy of skin disorders. Int. J. Mol. Sci. 2016, 17, 160. [CrossRef]

25. Popoola, O.K.; Marnewick, J.L.; Rautenbach, F.; Ameer, F.; Iwuoha, E.I.; Hussein, A.A. Inhibition of oxidative stress and skin aging-related enzymes by prenylated chalcones and other flavonoids from Helichrysum teretifolium. Molecules 2015, 20, 7143-7155. [CrossRef]

26. Sonka, L. Exploring Anti-Tyrosinase Bioactive Compounds from the Cape Flora. Master's Thesis, University of the Western Cape, Cape Town, South Africa, 2018.

27. Sagbo, I.J.; Otang-Mbeng, W. Evaluation of the efficacy of ethanol leaf extract of Helichrysum petiolare Hilliard and B.L. Burtt against skin aging. Trop. J. Pharm. Res. 2020, 19, 2631-2638. [CrossRef]

28. Zenze, K. Helichrysum cymosum (L.) D. Don Subsp. cymosum (Asteraceae). 2012. Available online: http://pza.sanbi.org/ helichrysum-cymosum-subsp-cymosum (accessed on 14 July 2021).

29. Maroyi, A. Helichrysum cymosum (L.) D. Don (Asteraceae): Medicinal uses, chemistry, and biological activities. Asian J. Pharm. Clin. Res. 2019, 12, 19-26. [CrossRef]

30. Van Vuuren, S.; Viljoen, A.; Van Zyl, R.; Van Heerden, F.; Başer, K.H.C. The anti-microbial, anti-malarial and toxicity profiles of helihumulone, leaf essential oil and extracts of Helichrysum cymosum (L.) D. Don subsp. cymosum. S. Afr. J. Bot. 2006, 72, 287-290. [CrossRef]

31. Heyman, H.M. Metabolomic Comparison of Selected Helichrysum Species to Predict Their Anti-Viral Properties. Ph.D. Thesis, University of Pretoria, Pretoria, South Africa, 2009.

32. Reddy, D. The Phytochemistry and Microbial Activity of Selected Indigenous Helichrysum Species. Ph.D. Thesis, University of the Witwatersrand, Johannesburg, South Africa, 2008.

33. Runyoro, D.; Ngassapa, O.; Kachali, L.; Obare, V.; Lyamuya, E. Biological activities of essential oils from plants growing in Tanzania. East Cent. Afr. J. Pharm. Sci. 2010, 13, 85-91.

34. Bougatsos, C.; Ngassapa, O.; Runyoro, D.K.; Chinou, I.B. Chemical composition and In Vitro antimicrobial activity of the essential oils of two Helichrysum species from Tanzania. Z. Nat. C 2004, 59, 368-372. [CrossRef]

35. Sindambiwe, J.; Calomme, M.; Cos, P.; Totte, J.; Pieters, L.; Vlietinck, A.; Berghe, D.V. Screening of seven selected Rwandan medicinal plants for anti-microbial and anti-viral activities. J. Ethnopharmacol. 1999, 65, 71-77. [CrossRef]

36. Stafford, G.; Jäger, A.; Van Staden, J. Effect of storage on the chemical composition and biological activity of several popular South African medicinal plants. J. Ethnopharmacol. 2005, 97, 107-115. [CrossRef]

37. Lourens, A.; Viljoen, A.M.; Van Heerden, F. South African Helichrysum species: A review of the traditional uses, biological activity and phytochemistry. J. Ethnopharmacol. 2008, 119, 630-652. [CrossRef]

38. Mukherjee, P.K. Anti-viral evaluation of herbal drugs. In Quality Control and Evaluation of Herbal Drugs; Elsevier: Amsterdam, The Netherlands, 2019; pp. 599-628.

39. Swelankomo, N. Helichrysum foetidum (L.) Moench (Asteraceae). 2005. Available online: http://pza.sanbi.org/helichrysumfoetidum (accessed on 14 July 2021).

40. Barcelos, L.; Heiden, G. First record of Helichrysum foetidum (L.) Moench (Asteraceae, Gnaphalieae) for South America. Check List 2017, 13, 331. [CrossRef]

41. Kakam, A.M.Z.; Franke, K.; Ndom, J.C.; Dongo, E.; Mpondo, T.N.; Wessjohann, L.A. Secondary metabolites from Helichrysum foetidum and their chemotaxonomic significance. Biochem. Syst. Ecol. 2011, 2, 166-167. [CrossRef] 
42. Maroyi, A. Medicinal uses, biological and phytochemical properties of Helichrysum foetidum (L.) Moench (Asteraceae). Asian J. Pharm. Clin. Res. 2019, 12, 13-18. [CrossRef]

43. Malolo, F.-A.E.; Nouga, A.B.; Kakam, A.; Franke, K.; Ngah, L.; Flausino, O.; Mpondo, E.M.; Ntie-Kang, F.; Ndom, J.C.; da Silva Bolzani, V. Protease-inhibiting, molecular modeling and antimicrobial activities of extracts and constituents from Helichrysum foetidum and Helichrysum mechowianum (compositae). Chem. Cent. J. 2015, 9, 1-11. [CrossRef]

44. Takagi, H.; Matsuzawa, H.; Ohta, T.; Yamasaki, M.; Inouye, M. Studies on the structure and function of subtilisin E by protein engineering. Ann. N. Y. Acad. Sci. 1992, 672, 52-59. [CrossRef]

45. Steenkamp, V.; Mathivha, E.; Gouws, M.; Van Rensburg, C. Studies on anti-bacterial, anti-oxidant and fibroblast growth stimulation of wound healing remedies from South Africa. J. Ethnopharmacol. 2004, 95, 353-357. [CrossRef] [PubMed]

46. Tirillini, B.; Menghini, L.; Leporini, L.; Scanu, N.; Marino, S.; Pintore, G. Anti-oxidant activity of methanol extract of Helichrysum foetidum Moench. Nat. Prod. Res. 2013, 27, 1484-1487. [CrossRef] [PubMed]

47. Leonov, A.; Arlia-Ciommo, A.; Piano, A.; Svistkova, V.; Lutchman, V.; Medkour, Y.; Titorenko, V.I. Longevity extension by phytochemicals. Molecules 2015, 20, 6544-6572. [CrossRef] [PubMed]

48. Kennedy, D.O.; Wightman, E.L. Herbal extracts and phytochemicals: Plant secondary metabolites and the enhancement of human brain function. Adv. Nutr. 2011, 2, 32-50. [CrossRef] [PubMed]

49. Bohlmann, F. Natuerlich vorkommende terpenderivate. Xxii. Uber ein neues azulen aus Helichrysum bracteatum (vent.) willd. Chem. Ber. 1973, 106, 1337-1340. [CrossRef] [PubMed]

50. Jakupovic, J.; Zdero, C.; Grenz, M.; Tsichritzis, F.; Lehmann, L.; Hashemi-Nejad, S.; Bohlmann, F. Twenty-one acylphloroglucinol derivatives and further constituents from South African Helichrysum species. Phytochemistry 1989, 28, 1119-1131. [CrossRef]

51. Heywood, V.H.; Harborne, J.B.; Turner, B.L. Biology and Chemistry of the Compositae; Academic Press: London, UK, 1977.

52. Van Vuuren, S. Antimicrobial activity of South African medicinal plants. J. Ethnopharmacol. 2008, 119, 462-472. [CrossRef] [PubMed]

53. Dias, C.N.; Rodrigues, K.A.; Carvalho, F.A.; Carneiro, S.M.; Maia, J.G.; Andrade, E.H.; Moraes, D.F. Molluscicidal and leishmanicidal activity of the leaf essential oil of Syzygium cumini (L.) Skeels from Brazil. Chem. Biodivers. 2013, 10, 1133-1141. [CrossRef] [PubMed]

54. Paul, K.; Ganguly, U.; Chakrabarti, S.; Bhattacharjee, P. Is 1, 8-cineole-rich extract of small cardamom seeds more effective in preventing Alzheimer's disease than 1, 8-cineole alone? Neuromol. Med. 2020, 22, 150-158. [CrossRef] [PubMed]

55. Vinholes, J.; Gonçalves, P.; Martel, F.; Coimbra, M.A.; Rocha, S.M. Assessment of the Anti-oxidant and anti-Proliferative effects of sesquiterpenic compounds in In Vitro caco-2 cell models. Food Chem. 2014, 156, 204-211. [CrossRef]

56. Lomarat, P.; Sripha, K.; Phanthong, P.; Kitphati, W.; Thirapanmethee, K.; Bunyapraphatsara, N. In Vitro biological activities of black pepper essential oil and its major components relevant to the prevention of Alzheimer's disease. Thai J. Pharm. Sci. (TJPS) 2015, 39, 94-101.

57. Cavaleiro, C.; Pinto, E.; Gonçalves, M.; Salgueiro, L. Anti-fungal activity of Juniperus essential oils against dermatophyte, Aspergillus and Candida strains. J. Appl. Microbiol. 2006, 100, 1333-1338. [CrossRef]

58. Alam, M. Anti-hypertensive effect of cereal anti-oxidant ferulic acid and its mechanism of action. Front. Nutr. 2019, 6, 121. [CrossRef]

59. Miao, M.; Xiang, L. Pharmacological action and potential targets of chlorogenic acid. Adv. Pharmacol. 2020, 87, 71-88.

60. Dhakad, A.K.; Pandey, V.V.; Beg, S.; Rawat, J.M.; Singh, A. Biological, medicinal and toxicological significance of eucalyptus leaf essential oil: A review. J. Sci. Food Agric. 2018, 98, 833-848. [CrossRef]

61. Müller, A.; Faubert, P.; Hagen, M.; Zu Castell, W.; Polle, A.; Schnitzler, J.-P.; Rosenkranz, M. Volatile profiles of fungi-chemotyping of species and ecological functions. Fungal Genet. Biol. 2013, 54, 25-33. [CrossRef]

62. Islam, M.T.; Ali, E.S.; Uddin, S.J.; Shaw, S.; Islam, M.A.; Ahmed, M.I.; Shill, M.C.; Karmakar, U.K.; Yarla, N.S.; Khan, I.N. Phytol: A review of biomedical activities. Food Chem. Toxicol. 2018, 121, 82-94. [CrossRef]

63. Perigo, C.V.; Torres, R.B.; Bernacci, L.C.; Guimaraes, E.F.; Haber, L.L.; Facanali, R.; Vieira, M.A.; Quecini, V.; Marques, M.O.M. The chemical composition and anti-bacterial activity of eleven piper species from distinct rainforest areas in southeastern Brazil. Ind. Crop. Prod. 2016, 94, 528-539. [CrossRef]

64. Moreira, C.M.; Fernandes, M.B.; Santos, K.T.; Schneider, L.A.; Da Silva, S.E.B.; Sant'Anna, L.S.; Paula, F.R. Effects of essential oil of Blepharocalyx salicifolius on cardiovascular function of rats. FASEB J. 2018, 32, 715-717. [CrossRef]

65. Dos Santos, E.; Radai, J.A.S.; do Nascimento, K.F.; Formagio, A.S.N.; de Matos Balsalobre, N.; Ziff, E.B.; Castelon Konkiewitz, E.; Kassuya, C.A.L. Contribution of spathulenol to the anti-nociceptive effects of Psidium guineense. Nutr. Neurosci. 2020, 1-11. [CrossRef] [PubMed]

66. Hsu, H.-C.; Yang, W.-C.; Tsai, W.-J.; Chen, C.-C.; Huang, H.-Y.; Tsai, Y.-C. A-bulnesene, a novel paf receptor antagonist isolated from Pogostemon cablin. Biochem. Biophys. Res. Commun. 2006, 345, 1033-1038. [CrossRef] [PubMed]

67. Govindarajan, M.; Rajeswary, M.; Benelli, G. $\Delta$-cadinene, calarene and $\delta$-4-carene from Kadsura heteroclita essential oil as novel larvicides against malaria, dengue and filariasis mosquitoes. Comb. Chem. High Throughput Screen. 2016, 19, 565-571. [CrossRef] [PubMed]

68. Ebani, V.V.; Mancianti, F. Use of essential oils in veterinary medicine to combat bacterial and fungal infections. Vet. Sci. 2020, 7, 193. [CrossRef] [PubMed]

69. Plant, R.M.; Dinh, L.; Argo, S.; Shah, M. The essentials of essential oils. Adv. Pediatrics 2019, 66, 111-122. [CrossRef] 
70. Helichrysum Petiolare. Available online: http:/ / pza.sanbi.org/helichrysum-petiolare (accessed on 19 June 2021).

71. Aladejana, A.E.; Bradey, G.; Afolayan, A.J. Comparative evaluation of essential oils of Helichrysum petiolare Hilliard \& B.L. Burtt obtained from solvent-free microwave and hydrodistillation extraction methods. Asain J. Chem. 2020, 32, 1-13.

72. Helichrysum cymosum (L.) D.Don Subsp. cymosum. Available online: https://keys.lucidcentral.org/keys/v3/helichrysum/key/ Helichrysum/Media/Html/Helichrysum_cymosum_subsp._cymosum.htm (accessed on 14 July 2021).

73. Franccedil, T.; Lambert, S.M.; Michel, J.D.P.; Gaby, N.M.E.; Fabrice, F.B.; Zaché, N.; Henri, A.Z.P.; Chantal, M. Composition, radical scavenging and anti-fungal activities of essential oils from 3 Helichrysum species growing in Cameroon against Penicillium oxalicum a yam rot fungi. Afr. J. Agric. Res. 2010, 5, 121-127.

74. Sobhy, E.; El-Feky, S. Chemical constituents and antimicrobial activity of Helichrysum stoechas. Asian J. Plant Sci. 2007, 6, 692-695. [CrossRef]

75. Najar, B.; Cervelli, C.; Ferri, B.; Cioni, P.; Pistelli, L. Essential oils and volatile emission of eight South African species of Helichrysum grown in uniform environmental conditions. S. Afr. J. Bot. 2019, 124, 178-187. [CrossRef]

76. Fiddle Everlasting (Helichrysum pandurifolium). Available online: https://www.inaturalist.org/observations/23571154 (accessed on 19 June 2021). 